\title{
Investigation of the Fatty Acid Contents of Edible Snails Helix lucorum, Eobania vermiculata and Non-Edible Slug Limax flavus İhsan Ekin $^{1 *}$ and Rıdvan Şeşen ${ }^{2}$
}

\author{
${ }^{I}$ Şırnak University, Engineering Faculty, Department of Energy Systems Engineering, Şırnak, Türkiye \\ ${ }^{2}$ Dicle University, Science Faculty, Biology Department, Diyarbakır, Türkiye
}

(Received February 22, 2017; Revised June 9, 2017; Accepted June 12, 2017)

\begin{abstract}
The purpose of this work is to reveal the fatty acid composition of phospholipids, neutral and total lipid content of edible land snails Helix lucorum, Eobania vermiculata and non-edible land slug Limax flavus

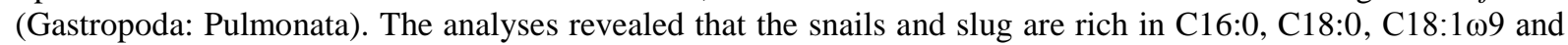

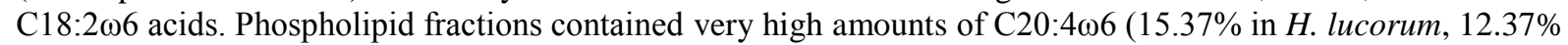
in E. vermiculata and $8.59 \%$ in L. flavus) which is the most important precursor of eicosanoids. The level of $\Sigma$ PUFA, in edible snails, was found to be higher than $\Sigma$ SFA and $\Sigma$ MUFA. However, in the slug, $\Sigma$ MUFA level was higher than $\Sigma$ SFA and $\Sigma$ PUFA levels in neutral and total lipid contents. $\Sigma \omega 6 / \Sigma \omega 3$ (Omega $6 /$ Omega 3) ratio was defined to be very high in the phospholipid of H. lucorum, E. vermiculata and L. flavus; 6.07, 8.29 and 5.39, respectively. Furthermore, the study showed that all three species are valuable sources of omega 6 and

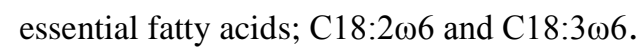

Keywords: Fatty acids, Helix lucorum; Eobania vermiculata; Limax flavus. (C2017 ACG Publications. All rights reserved.

\section{Animal Source}

H. lucorum (L. 1758) and L. flavus (L. 1758) were collected from Hevsel Gardens and residential gardens located in Diyarbakır, respectively and E. vermiculata (O. F. Müller 1774) was collected from residential gardens located in Şanlıurfa, Türkiye, on March 2014. Individually, three snails and slugs of similar size (H. lucorum: length: $6 \pm 1.00 \mathrm{~cm}$, wet flesh weight: $7 \pm 1.25 \mathrm{~g} ; E$. vermiculata: $4 \pm 0.50 \mathrm{~cm}$, wet flesh weight: $3 \pm 0.75$; L. flavus: length: $7 \pm 1.00 \mathrm{~cm}$, wet flesh weight: $5 \pm 1.25 \mathrm{~g}$ ) were sampled for each lipid analysis, 27 samples in total, for three replicates of all lipid analyses.

\section{Previous Studies}

Cultivated terrestrial gastropods mostly consist of Helix pomatia, H. aspersa maxima and Achatina achatina all over the world. In Türkiye, the edible land snails are represented by Theba pisana, Eobania vermiculata, Cantareus apertus, H. asemnis, H. cincta and $H$. lucorum. Although, these snails are not consumed by Turkish people, they are exported mainly to European countries such as France, Germany, Greece, Italy, and Spain for consuming [1]. Together with taste, snail meat (escargot) has several advantages over others such as calorific values, rich mineral, essential amino acids and fatty acids content, especially, PUFA (polyunsaturated fatty acids). Fatty acid contents of marine molluscs [2-4] have been more extensively studied then land representatives. Few

\footnotetext{
*Corresponding author. E-mail: ekinihsan@gmail.com 
investigations have been carried out on edible terrestrial forms [1,5-8], particularly, on the content of phospholipid, neutral and total lipids. However, in Türkiye, little is known about nutritional value of land gastropods and their fatty acid compositions.

Tablo 1. Fatty acid composition of phospholipid, neutral lipid and total lipid of Helix lucorum

\begin{tabular}{|c|c|c|c|}
\hline Fatty acids & $\begin{array}{l}\text { Phospholipid } \\
\left(\text { Mean }^{*} \pm \text { S.D. }\right)^{* *}\end{array}$ & $\frac{\text { Neutral lipid }}{\left(\text { Mean }^{*} \pm \text { S.D. }\right)^{* *}}$ & $\frac{\text { Total lipid }}{\left(\text { Mean }^{*} \pm \text { S.D. }\right)^{* *}}$ \\
\hline C10:0 & $0.05 \pm 0.02 \mathrm{a}$ & $0.05 \pm 0.02 \mathrm{a}$ & $0.03 \pm 0.01 \mathrm{a}$ \\
\hline C12:0 & $0.03 \pm 0.01 \mathrm{a}$ & - & $0.04 \pm 0.01 \mathrm{a}$ \\
\hline C13:0 & $0.02 \pm 0.01 \mathrm{a}$ & $0.02 \pm 0.01 \mathrm{a}$ & $0.05 \pm 0.02 b$ \\
\hline C14:0 & $0.94 \pm 0.11 \mathrm{a}$ & $0.60 \pm 0.08 b$ & $0.53 \pm 0.06 b$ \\
\hline C15:0 & $0.60 \pm 0.07 \mathrm{a}$ & $0.36 \pm 0.05 b$ & $0.69 \pm 0.06 \mathrm{a}$ \\
\hline C16:0 & $12.92 \pm 1.48 \mathrm{a}$ & $9.29 \pm 1.05 b$ & $9.66 \pm 1.10 \mathrm{~b}$ \\
\hline C17:0 & $1.90 \pm 0.20 \mathrm{a}$ & $1.00 \pm 0.14 \mathrm{~b}$ & $1.25 \pm 0.10 \mathrm{~b}$ \\
\hline C18:0 & $9.02 \pm 1.02 \mathrm{a}$ & $7.00 \pm 0.72 b$ & $6.75 \pm 0.55 b$ \\
\hline C20:0 & $0.18 \pm 0.06 \mathrm{a}$ & $0.10 \pm 0.03 \mathrm{~b}$ & $0.20 \pm 0.04 \mathrm{a}$ \\
\hline $\mathrm{C} 22: 0$ & $2.40 \pm 0.35 \mathrm{a}$ & $2.00 \pm 0.23 \mathrm{a}$ & $2.50 \pm 0.24 \mathrm{a}$ \\
\hline ¿SFA & $28.06 \pm 1.70 a$ & $20.42 \pm 1.35 b$ & $21.70 \pm 1.44 b$ \\
\hline $\mathrm{C} 14: 1 \omega 9$ & - & $0.19 \pm 0.04 \mathrm{a}$ & $0.25 \pm 0.06 a$ \\
\hline 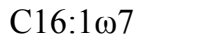 & $1.94 \pm 0.30 \mathrm{a}$ & $1.93 \pm 0.28 \mathrm{a}$ & $1.86 \pm 0.24 \mathrm{a}$ \\
\hline $\mathrm{C} 17: 1 \omega 7$ & $0.30 \pm 0.04 \mathrm{a}$ & $0.20 \pm 0.04 \mathrm{a}$ & - \\
\hline 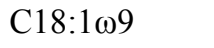 & $11.29 \pm 1.14 \mathrm{a}$ & $24.17 \pm 1.66 b$ & $22.02 \pm 1.48 \mathrm{~b}$ \\
\hline 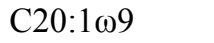 & $3.34 \pm 0.30 \mathrm{a}$ & $1.28 \pm 0.13 b$ & $1.50 \pm 0.16 \mathrm{~b}$ \\
\hline 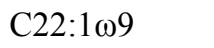 & $0.50 \pm 0.06 \mathrm{a}$ & - & $0.90 \pm 0.08 \mathrm{a}$ \\
\hline 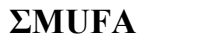 & $17.37 \pm 1.18 a$ & $27.77 \pm 1.60 b$ & $26.53 \pm 1.55 b$ \\
\hline $\mathrm{C} 18: 2 \omega 6$ & $20.25 \pm 1.30 \mathrm{a}$ & $21.28 \pm 1.25 \mathrm{a}$ & $21.76 \pm 1.27 \mathrm{a}$ \\
\hline $\mathrm{C} 20: 2 \omega 6$ & $8.33 \pm .0 .90 \mathrm{a}$ & $7.02 \pm 0.72 b$ & $6.90 \pm 0.71 b$ \\
\hline $\mathrm{C} 20: 3 \omega 6$ & $2.14 \pm 0.25 \mathrm{a}$ & $1.72 \pm 0.18 \mathrm{a}$ & $1.87 \pm 0.18 \mathrm{a}$ \\
\hline $\mathrm{C} 20: 4 \omega 6$ & $15.37 \pm 1.19 \mathrm{a}$ & $9.64 \pm 1.02 b$ & $9.85 \pm 1.06 b$ \\
\hline $\mathrm{C} 22: 5 \omega 6$ & $0.75 \pm 0.09 \mathrm{a}$ & $0.55 \pm 0.05 \mathrm{a}$ & $0.60 \pm 0.07 \mathrm{a}$ \\
\hline Total $\omega 6$ & 46.84 & 40.21 & 40.98 \\
\hline $\mathrm{C} 18: 3 \omega 3$ & $6.09 \pm 0.70 \mathrm{a}$ & $10.50 \pm 0.90 b$ & $10.08 \pm 0.84 b$ \\
\hline $\mathrm{C} 20: 5 \omega 3$ & $0.92 \pm 0.08 \mathrm{a}$ & $0.66 \pm 0.06 b$ & $0.71 \pm 0.07 b$ \\
\hline $\mathrm{C} 22: 6 \omega 3$ & $0.70 \pm 0.06 \mathrm{a}$ & $0.44 \pm 0.04 b$ & - \\
\hline Total $\omega 3$ & 7.71 & 11.60 & 10.79 \\
\hline$\Sigma \omega 6 / \Sigma \omega 3$ & 6.07 & 3.47 & 3.80 \\
\hline 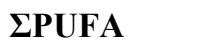 & $54.55 \pm 2.32 \mathrm{a}$ & $51.81 \pm 2.14 b$ & $51.77 \pm 2.08 b$ \\
\hline 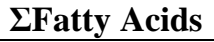 & 99.98 & 100.00 & 100.00 \\
\hline
\end{tabular}

\section{Present Study}

Preparation of Gastropods and Lipid Extraction: The shells and the digestive organs of the gastropods were carefully removed and fleshy parts were analyzed. They were washed and cut into tiny pieces. Each group of samples was transferred into chloroform / methanol $(2: 1, \mathrm{v} / \mathrm{v})$ bottles and kept frozen $\left(-80^{\circ} \mathrm{C}\right)$ until use. The phospholipids, neutral and total lipids of the snails and slugs were extracted according to the method of Bligh and Dyer [9].

Gas Chromatography (GC) Conditions: Fatty acid methyl esters (FAME) of the total, neutral and phospholipids were prepared according to an existing method [10]. 
Tablo 2. Fatty acid composition of phospholipid, neutral lipid and total lipid content of Eobania vermiculata

\begin{tabular}{|c|c|c|c|}
\hline Fatty acids & $\begin{array}{c}\text { Phospholipid } \\
\left(\text { Mean }^{*} \pm \text { S.D. }\right)^{* *}\end{array}$ & $\begin{array}{l}\text { Neutral lipid } \\
\left(\text { Mean }^{*} \pm \text { S.D. }\right)^{* *}\end{array}$ & $\frac{\text { Total lipid }}{\left(\text { Mean }^{*} \pm \text { S.D. }\right)^{* *}}$ \\
\hline \multicolumn{4}{|l|}{ Saturated } \\
\hline C10:0 & - & $0.05 \pm 0.01 \mathrm{a}$ & $0.05 \pm 0.01 \mathrm{a}$ \\
\hline C12:0 & $0.33 \pm 0.04 \mathrm{a}$ & $0.21 \pm 0.03 b$ & $0.12 \pm 0.02 \mathrm{c}$ \\
\hline C13:0 & $1.08 \pm 0.10 \mathrm{a}$ & $0.78 \pm 0.09 b$ & $0.81 \pm 0.09 b$ \\
\hline C14:0 & $0.63 \pm 0.05 a$ & $0.37 \pm 0.04 b$ & $0.30 \pm 0.03 b$ \\
\hline $\mathrm{C} 15: 0$ & $0.88 \pm 0.09 \mathrm{a}$ & $0.22 \pm 0.03 b$ & $0.33 \pm 0.03 b$ \\
\hline C16:0 & $14.61 \pm 1.08 \mathrm{a}$ & $12.49 \pm 0.95 b$ & $10.49 \pm 0.90 \mathrm{c}$ \\
\hline C17:0 & $0.98 \pm 0.09 \mathrm{a}$ & $0.91 \pm 0.09 \mathrm{a}$ & $1.02 \pm 0.14 \mathrm{a}$ \\
\hline C18:0 & $10.37 \pm 0.95 \mathrm{a}$ & $7.12 \pm 0.73 b$ & $7.76 \pm 0.75 b$ \\
\hline C20:0 & $0.20 \pm 0.03 \mathrm{a}$ & $0.25 \pm 0.03 a$ & - \\
\hline $\mathrm{C} 22: 0$ & $1.35 \pm 0.15 \mathrm{a}$ & $1.20 \pm 0.14 \mathrm{a}$ & $1.80 \pm 0.17 \mathrm{a}$ \\
\hline$\Sigma S F A$ & $30.43 \pm 1.80 a$ & $23.60 \pm 1.35 b$ & $22.68 \pm 1.34 b$ \\
\hline 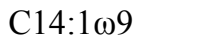 & $0.10 \pm 0.02 \mathrm{a}$ & - & $0.07 \pm 0.01 \mathrm{a}$ \\
\hline $\mathrm{C} 16: 1 \omega 7$ & $2.80 \pm 0.26 \mathrm{a}$ & $1.08 \pm 0.18 \mathrm{~b}$ & $1.60 \pm 0.15 b$ \\
\hline $\mathrm{C} 17: 1 \omega 7$ & $0.09 \pm 0.02 \mathrm{a}$ & $0.08 \pm 0.02 \mathrm{a}$ & $0.12 \pm 0.03 b$ \\
\hline 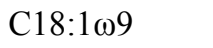 & $13.09 \pm 0.96 \mathrm{a}$ & $20.04 \pm 1.26 b$ & $19.07 \pm 1.18 b$ \\
\hline 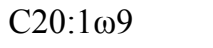 & $2.24 \pm 0.26 \mathrm{a}$ & $0.39 \pm 0.04 b$ & $0.21 \pm 0.03 b$ \\
\hline $\mathrm{C} 22: 1 \omega 9$ & $0.30 \pm 0.03 \mathrm{a}$ & $0.27 \pm 0.03 \mathrm{a}$ & $0.70 \pm 0.05 b$ \\
\hline इMUFA & $18.62 \pm 1.18 a$ & $21.86 \pm 1.36 b$ & $21.77 \pm 1.30 b$ \\
\hline 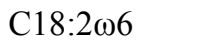 & $25.87 \pm 1.36 \mathrm{a}$ & $34.92 \pm 1.99 b$ & $37.67 \pm 1.83 \mathrm{c}$ \\
\hline $\mathrm{C} 20: 2 \omega 6$ & $6.29 \pm 0.60 \mathrm{a}$ & $5.44 \pm 0.52 b$ & $5.43 \pm 0.50 \mathrm{~b}$ \\
\hline $\mathrm{C} 20: 3 \omega 6$ & $0.77 \pm 0.05 \mathrm{a}$ & $0.61 \pm 0.04 b$ & $0.56 \pm 0.04 b$ \\
\hline $\mathrm{C} 20: 4 \omega 6$ & $12.37 \pm 0.95 \mathrm{a}$ & $5.05 \pm 0.42 b$ & $3.54 \pm 0.37 \mathrm{c}$ \\
\hline $\mathrm{C} 22: 5 \omega 6$ & $0.15 \pm 0.02 \mathrm{a}$ & $0.14 \pm 0.02 \mathrm{a}$ & $0.17 \pm 0.03 \mathrm{a}$ \\
\hline Total $\omega 6$ & 45.45 & 46.16 & 47.37 \\
\hline $\mathrm{C} 18: 3 \omega 3$ & $4.14 \pm 0.40 \mathrm{a}$ & $7.49 \pm 0.72 b$ & $7.31 \pm 0.74 b$ \\
\hline $\mathrm{C} 20: 5 \omega 3$ & $1.02 \pm 0.16 \mathrm{a}$ & $0.48 \pm 0.04 b$ & $0.37 \pm 0.03 b$ \\
\hline $\mathrm{C} 22: 6 \omega 3$ & $0.32 \pm 0.03 \mathrm{a}$ & - & $0.51 \pm 0.04 \mathrm{a}$ \\
\hline Total $\omega 3$ & 5.48 & 7.97 & 8.19 \\
\hline$\Sigma \omega 6 / \Sigma \omega 3$ & 8.29 & 5.79 & 5.78 \\
\hline 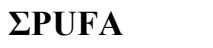 & $50.93 \pm 2.02 a$ & $54.53 \pm 2.14 b$ & $55.56 \pm 2.18 b$ \\
\hline 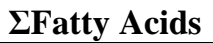 & 99.98 & 99.99 & 100.01 \\
\hline
\end{tabular}

Statistical Analyses: The data of analyses were obtained by statistical program (SPSS 12.0). All analytical values were performed in triplicate and the mean values were calculated. The statistical analyses of fatty acid proportions were performed by analysis of variance (ANOVA) and comparisons between means were performed with Tukey's test. Differences between means were evaluated as significant at $\mathrm{P} \leq 0.05$.

The fatty acids percentages of total, neutral and phospholipid contents from the snail samples and slug samples are presented in the Tables 1,2, and 3. All species contained about 5 to 9 times higher content of $\omega 6$ (omega 6) than $\omega 3$ (omega 3) (Table 1, 2, 3) and C18:2 $\omega 6$ and C20:4 $\omega 6$ lipids constitutes the highest proportions of $\omega 6$. The level of $\Sigma$ PUFA in edible snails was found to be higher than $\Sigma$ SFA (saturated fatty acids) and $\Sigma$ MUFA (monounsaturated fatty acids). However, in the slug samples, $\Sigma$ MUFA level found to be higher than $\Sigma$ SFA and $\Sigma$ PUFA levels in terms of neutral and total lipid content. 
Table 3. Fatty acid composition of phospholipid, neutral lipid and total lipid content of Limax flavus.

\begin{tabular}{|c|c|c|c|}
\hline Fatty acids & Phospholipid & Neutral lipid & Total lipid \\
\hline & $\left(\right.$ Mean $^{*}{ }$ S.D. $) * *$ & $\left(\right.$ Mean $^{*} \pm$ S.D. $) * *$ & $\left(\right.$ Mean $^{*} \pm$ S.D. $) * *$ \\
\hline C10:0 & $1.30 \pm 0.12 \mathrm{a}$ & $0.18 \pm 0.03 \mathrm{~b}$ & $1.95 \pm 0.24 \mathrm{a}$ \\
\hline C12:0 & $1.42 \pm 0.16 \mathrm{a}$ & $0.68 \pm 0.05 b$ & $1.03 \pm 0.10 \mathrm{a}$ \\
\hline C13:0 & - & $0.29 \pm 0.03 \mathrm{a}$ & $0.50 \pm 0.04 \mathrm{~b}$ \\
\hline C14:0 & $4.44 \pm 0.38 \mathrm{a}$ & $3.30 \pm 0.25 b$ & $4.62 \pm 0.36 \mathrm{a}$ \\
\hline $\mathrm{C} 15: 0$ & $0.56 \pm 0.04 a$ & $0.50 \pm 0.04 \mathrm{a}$ & $0.55 \pm 0.04 a$ \\
\hline C16:0 & $23.10 \pm 1.21 \mathrm{a}$ & $22.13 \pm 1.20 \mathrm{a}$ & $20.53 \pm 1.18 b$ \\
\hline C17:0 & $0.20 \pm 0.02 \mathrm{a}$ & $0.40 \pm 0.04 \mathrm{~b}$ & $0.20 \pm 0.02 \mathrm{a}$ \\
\hline C18:0 & $7.01 \pm 0.65 \mathrm{a}$ & $5.18 \pm 0.45 b$ & $5.54 \pm 0.47 \mathrm{~b}$ \\
\hline C20:0 & $0.15 \pm 0.03 \mathrm{a}$ & $0.20 \pm 0.04 \mathrm{a}$ & $0.10 \pm 0.03 \mathrm{a}$ \\
\hline $\mathrm{C} 22: 0$ & $3.10 \pm 0.25 \mathrm{a}$ & $3.20 \pm 0.35 \mathrm{a}$ & $2.70 \pm 0.27 \mathrm{a}$ \\
\hline 玉SFA & $41.28 \pm 2.07 a$ & $36.06 \pm 1.90 b$ & $37.72 \pm 1.91 b$ \\
\hline $\mathrm{C} 14: 1 \omega 9$ & $0.30 \pm 0.03 \mathrm{a}$ & $0.29 \pm 0.03 \mathrm{a}$ & - \\
\hline $\mathrm{C} 16: 1 \omega 7$ & $2.71 \pm 0.28 \mathrm{a}$ & $5.18 \pm 0.49 b$ & $4.75 \pm 0.42 b$ \\
\hline $\mathrm{C} 17: 1 \omega 7$ & $0.70 \pm 0.06 \mathrm{a}$ & $0.60 \pm 0.05 \mathrm{a}$ & $0.70 \pm 0.06 \mathrm{a}$ \\
\hline $\mathrm{C} 18: 1 \omega 9$ & $20.06 \pm 1.20 \mathrm{a}$ & $32.20 \pm 1.75 b$ & $31.94 \pm 1.70 b$ \\
\hline $\mathrm{C} 20: 1 \omega 9$ & $1.01 \pm 0.11 \mathrm{a}$ & $1.03 \pm 0.12 \mathrm{a}$ & $1.02 \pm 0.12 \mathrm{a}$ \\
\hline $\mathrm{C} 22: 1 \omega 9$ & $0.30 \pm 0.02 \mathrm{a}$ & $0.50 \pm 0.04 \mathrm{a}$ & - \\
\hline इMUFA & $25.08 \pm 1.24 a$ & $39.80 \pm 1.95 b$ & $38.41 \pm 1.83 b$ \\
\hline $\mathrm{C} 18: 2 \omega 6$ & $15.18 \pm 1.11 \mathrm{a}$ & $14.81 \pm 1.08 \mathrm{a}$ & $13.03 \pm 1.04 \mathrm{a}$ \\
\hline $\mathrm{C} 20: 2 \omega 6$ & $2.70 \pm 0.23 \mathrm{a}$ & $2.26 \pm 0.20 \mathrm{a}$ & $2.49 \pm 0.22 \mathrm{a}$ \\
\hline $\mathrm{C} 20: 3 \omega 6$ & $1.08 \pm 0.18 \mathrm{a}$ & $0.21 \pm 0.02 b$ & $0.30 \pm 0.02 b$ \\
\hline $\mathrm{C} 20: 4 \omega 6$ & $8.59 \pm 0.75 \mathrm{a}$ & $2.24 \pm 0.20 \mathrm{~b}$ & $3.48 \pm 0.29 \mathrm{c}$ \\
\hline $\mathrm{C} 22: 2 \omega 6$ & $0.82 \pm 0.09 a$ & $0.76 \pm 0.06 \mathrm{a}$ & $0.50 \pm 0.04 b$ \\
\hline Total $\omega 6$ & 28.37 & 20.28 & 19.80 \\
\hline $\mathrm{C} 18: 3 \omega 3$ & $2.56 \pm 0.28 \mathrm{a}$ & $2.26 \pm 0.26 \mathrm{a}$ & $2.13 \pm 0.20 \mathrm{a}$ \\
\hline $\mathrm{C} 20: 5 \omega 3$ & $2.20 \pm 0.21 \mathrm{a}$ & $1.15 \pm 0.13 b$ & $1.92 \pm 0.18 \mathrm{a}$ \\
\hline $\mathrm{C} 22: 6 \omega 3$ & $0.50 \pm 0.04 \mathrm{a}$ & $0.45 \pm 0.03 a$ & - \\
\hline Total $\omega 3$ & 5.26 & 3.86 & 4.05 \\
\hline$\Sigma \omega 6 / \Sigma \omega 3$ & 5.39 & 5.25 & 4.89 \\
\hline IPUFA & $33.63 \pm 1.34 a$ & $24.14 \pm 1.18 b$ & $23.85 \pm 1.17 b$ \\
\hline इFatty Acids & 99.99 & 100.00 & 99.98 \\
\hline
\end{tabular}

The results of the current study declared that the fatty acid profiles of the snails and slug revealed common patterns of fatty acids and common characteristics to gastropods in general [4-6, 11$14]$.

According to the result of a slug study, in the slugs C16:0 (6.7\% - 10.1\%), C18:0 (9.1\% $10.7 \%), \mathrm{C} 18: 1 \omega 9(12.1 \%-15.7 \%), \mathrm{C} 18: 2 \omega 6(11.6 \%-15.2 \%)$ and $\mathrm{C} 20: 4 \omega 6(13.5 \%-14.3 \%)$; in the

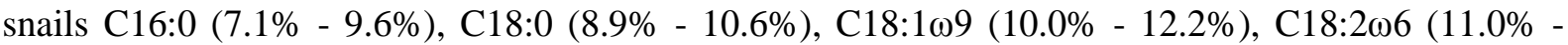
$15.7 \%), \mathrm{C} 20: 2 \omega 6(9.1 \%-12.1 \%)$ and $\mathrm{C} 20: 4 \omega 6(13.8 \%-16.9 \%)$ were determined as predominant components of land slugs Arion ater, Limax maximus, Prophysaon andersoni and land snails Helix sp. Haplotrema sportella, Vespericola columbiana [6]. In another study, C16:0 (6.14\% - 10.79\%), $\mathrm{C} 18: 1 \omega 9(17.12 \%-29.22 \%)$ and $\mathrm{C} 18: 2 \omega 6(2.87 \%$ - 8.40\%) in Valvata baicalensis; C16:0 (5.48\% $12.32 \%), \mathrm{C} 18: 1 \omega 9(16.13 \%-31.33 \%)$ and $\mathrm{C} 18: 2 \omega 6(1.59 \%-9.42 \%)$ were reported as principal components of Valvata piligera [15]. Similarly, high percentages of these fatty acids were also found in freshwater gastropods Melanopsis praemorsum, Melanoides tuberculata, Theodoxus jordani and Pyrigula barroisi [13] and they were also detected as main fatty acids in $H$. aspersa [8] and $H$. pomatia [7]. In the present study, the levels of C16:0, C18:1 $\omega 9$ and $\mathrm{C} 18: 2 \omega 6$ were similarly found higher. The other noteworthy data of the study was the detection of C13:0, C15:0, C17:0, C14:1 $\omega 9$ and $\mathrm{C} 17: 1 \omega 7$ from all lipid analyses. These fatty acids were not detected in the slugs and snails mentioned in the study of Zhu et al., [6] and most of the other studies. 
The ratio of $\Sigma \omega 6 / \Sigma \omega 3$ was reported higher in P. andersoni, A. ater, L. maximus slugs and $H$. sp. H. sportella, $V$. columbiana snails [6]. In most of the previous studies, the percentage of $\Sigma \omega 3$ was observed higher than $\Sigma \omega 6$ in marine molluscs and the ratio of $\Sigma \omega 6 / \Sigma \omega 3$ was lower than terrestrial forms $[2,4]$. The differences in the omega fatty acid profiles of molluscs is potentially due to dietary differences since marine plankton are rich in $\omega 3$ acids while terrestrial and freshwater plants and planktons are rich in $\omega 6$ acids [16].

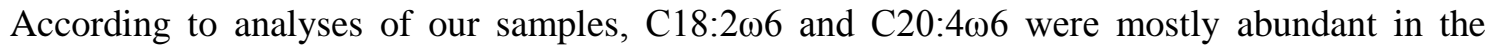
phospholipids fractions of three species. C20:4 06 is an important component of phospholipid, particularly in phosphatidylinositol subclass [17] and it is necessary for series 2 prostaglandins synthesizing mostly from $\mathrm{C} 20: 4 \omega 6$ of membrane phospholipids [2]. Prostaglandins appear to be considerably significant component of molluscs in basic physiological functions, particularly in ion regulation, renal function and reproduction [18]. Probably, higher levels of these fatty acids have been related to prostaglandin synthesis of the species. Also, the quantity of C20:4 66 was reported much higher levels than the most of the terrestrial and freshwater gastropods $[6,13,19]$ which are close relatives of land snails and slugs. In the present study, the percentages of $\mathrm{C} 20: 5 \omega 3$ did not exceed $2.20 \%$ in any sample studied. Lower levels of $\mathrm{C} 20: 503$ in the snails and slug is expected since, Isay and Busarova [20] mentioned $\mathrm{C} 20: 503$ is a characteristic component of marine invertebrates as a result of fatty acid analysis of 51 species of marine invertebrates (most of them were molluscs) from Japanese Sea.

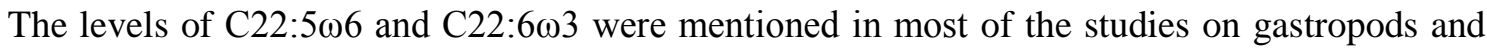
bivalves such as Coretus carneus, Viviparus viviparus, Radix auricularia, Limnaea stagnalis, Dreissena polymorpha, Unio sp. [19], Assyriella escheriana and A. guttata [21]. Additionally, in some studies, the high content of $\mathrm{C} 22: 6 \omega 3(10 \%-27 \%)$ was reported in marine oysters, clams and scallops

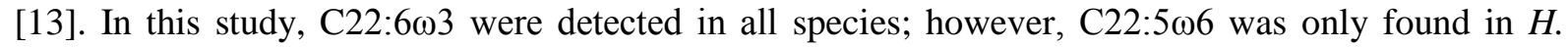
lucorum and E. vermiculata, furthermore, the quantities of $\mathrm{C} 22: 6 \omega 3$ and $\mathrm{C} 22: 5 \omega 6$ did not exceed 1\%. The type and composition of fatty acids is found different between mollusc species because of their environmental conditions, nutrient habits, food availability and physiological activities.

Non-methylene interrupted dienoic (NMID) fatty acids were reported in both marine [2, 4], and some freshwater [14] molluscs, as well as in some freshwater fish [22]. Their structures were known as $\mathrm{C} 20: 2 \Delta^{5-11}, \mathrm{C} 20: 2 \Delta^{5-13}, \mathrm{C} 22: 2 \Delta^{7-13}$ and $\mathrm{C} 22: 2 \Delta^{7-15}$. Some authors suppose that in aquatic invertebrates, these fatty acids have an endogenous origin $[23,24]$. As it has been mentioned in the most of the other freshwater mollusc studies, none of the NMID fatty acids were detected in the current study.

The fatty acid compositions of selected tissues of $H$. lucorum including gonad, mantle, digestive gland, cephalopedal and whole body of H. lucorum were studied in detail in our previous studies [25]; however, the fatty acid composition of lipid classes of E. vermiculata and L. flavus were not studied. As a result, current study can be a significant guide for nutritional value and quantitative analysis of edible snails of Türkiye. On the other hand, the study can be useful for comparison of further investigations on systematic and physiological studies of new species.

\section{References}

[1] M. Z. Yıldırım and Ü. Kebapçı (2004). Slugs (Gastropoda: Pulmonata) of the Lakes Region (Göller Bölgesi) in Turkey, T.J. Zoology. 28, 155-160.

[2] M. Abad, C. Ruiz, D. Martinez, G. Mosquera and J. L. Sanchez (1995). Seasonal variation of lipid classes and fatty acids in $\mathrm{fl}$ at oyster, Ostrea edulis, from San Cibrian (Galicia, Spain), Comp. Biochem. Physiol. 110C (2), 109-118.

[3] J. A. Pazos, C. Ruiz, G. O. Martin, M. Abad and L. J. Sanchez (1996). Seasonal variation of the lipid content and fatty acid composition of Crassostrea gigas cultured in El Grove, Galicia, N.W. Spain, Comp. Biochem. Physiol. 114B (2), 171-179.

[4] J. A. Pazos, L. J. Sanchez, G. Roman, M. L. Perez-Parelle and M. Abad (2003). Seasonal changes in lipid classes and fatty acids composition in digestive gland of Pecten maximus, Comp. Biochem. Physiol. 134B, 367-380. 
[5] H. J. Stavrakakis, S. K. Mastronicolis and V. M. Kapoulas (1989). Lipid composition and structural studies on lipids from the land snail Eobania vermiculata, Z. Naturforsch. 44C, 597-608.

[6] N. Zhu, X. Dai, S. D. Lin and W. E. Cornor (1994). The lipids of slugs and snails: Evolution, diet and biosynthesis, Lipids. 29, 869-875.

[7] Y. Özoğul, F. Özoğul and I. A. Olgunoğlu (2005). Fatty acid profile and mineral content of the wild snail (Helix pomatia) from the region of south of the Turkey, Eur. Food Res. Technol. 221, 547-549.

[8] F. Çağıltay, N. Erkan, D. Tosun and A. Selçuk (2011). Amino acid, fatty acid, vitamin and mineral contents of edible garden snail (Helix aspersa), J. FisheriesSciences.com. 5(4), 354-363.

[9] E. G. Bligh and W. J. A. Dyer (1959). A rapid method of total lipid extraction and purification, Can. J. Biochem. Physiol. 37, 911-917.

[10] D. W. Stanley-Samuelson and R. H. Dadd (1983). Long chain polyunsaturated fatty acids: Patterns of occurrence in insects, Biochemistry. 13, 549-558.

[11] K. Mai, J. P. Mercer and J. Donlon (1996). Comparative studies on the nutrition of two species of abalone Haliotis tuberculata L. and Haliotis discus hannai. Ino. V. The role of polyunsaturated fatty acid of macroalgae an abalone nutrition, Aquaculture. 139, 77-89.

[12] S. Rakshit, K. D. Bhattacharyya and K. K. Misra (1997). Distribution of major lipids and fatty acids of the estuarine gastropod mollusc Telescopium telescopium, Folia Biologica (Krakow), 45, 83-87.

[13] J. V. Go, T. Rezanka, M. Srebnik and V. M. Dembitsky (2002). Variability of fatty acid component of marine and freshwater gastropod species from the littoral zone of the Red Sea, Mediterranean Sea and Sea of Galilee, Biochem. Syst. Ecol. 30, 819-835.

[14] K. K. Misra, I. Shkrob, S. Rakshit and V. M. Dembitsky (2002). Variability in fatty acids and fatty aldehydes in different organs of two prosobranch gastropod molluscs, Biochem. Syst. Ecol. 30, 749-761.

[15] V. M. Dembitsky, T. Rezanka and A. G. Kashin (1994). Comparative study of the endemic freshwater fauna of lake Baikal-IV. Phospholipids and fatty acid composition of two gastropod molluscs of the genus Valvata, Comp. Biochem. Physiol. 107B, 325-330.

[16] J. R. Sargent (1976). The structure, metabolism and function of lipids in marine organisms. In: Biochemical and Biophysical Perspectives in Marine Biolog, D.C. Malin and J. R. Sargent Ed., 149212, Academic Press, London.

[17] D. R. Tocher and J. R. Sargent (1984). Analysis of lipids and fatty acids in ripe-roes of some Northwest European marine fish, Lipids. 19, 492-499.

[18] D. W. Stanley-Samuelson (1987). Physiological roles of prostaglandins and other eicosanoids in invertebrates, Biol. Bull. 173, 92-109.

[19] V. M. Dembitsky, A. G. Kashin and K. Stefanow (1992). Comparative investigation of phospholipids and fatty acids of freshwater molluscs from Volga River Basin, Comp. Biochem. Physiol. 102B, 193198.

[20] V. S. Isay and N. G. Busarova (1984). Study on fatty acids composition of marine organisms-I. Unsaturated fatty acids of Japan Sea invertebrates, Comp. Biochem. Physiol. 77B (4), 803-810.

[21] İ. Ekin (2015). A comparative study on fatty acid content of main organs and lipid classes of land snails Assyriella escheriana and Assyriella guttata distributed in Southeastern Anatolia, Ital. J. Food Sci. 27, 75-81.

[22] R. G. Ackman, C. McLeod, S. Rakshit and K. K. Misra (2002). Lipids and fatty acids of five freshwater food fishes of India, J. Food Lipids. 9, 127-145.

[23] J. D. Joseph (1982). Lipid composition of marine and estuarine invertebrates. Part II: Mollusca, Prog. Lipid Res. 21, 109-153.

[24] N. V. Zhukova (1991). The pathway of the biosynthesis of nonmethylene- interrupted dienoic fatty acids in molluscs, Comp. Biochem. Physiol. 110B, 801-804.

[25] İ. Ekin (2014). Distribution of fatty acids and total lipids in five tissues of edible snail Helix lucorum (L., 1758) from the Southeast of Turkey, Ital. J. Food Sci. 26 (1), 56-61.

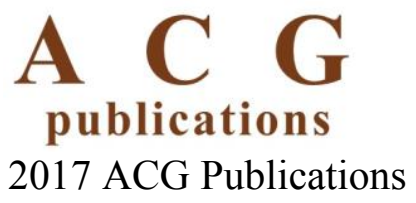

